\title{
Chronic sclerosing sialadenitis: report of a rare and atypical case
}

Sialodenite crônica esclerosante: relato de caso raro e atípico

Sialodenitis esclerosante crónica: informe raro y atípico

\section{Rafaela Savio MELZER' \\ Cintia Mussi MILANI ${ }^{2}$ \\ Fernanda Noguez SUM1 \\ Rui Cesar de Bittencourt DRUSZCZ3 \\ Juliana Lucena SCHUSSEL ${ }^{4}$}

${ }^{1}$ Department of Stomatology, Post Graduate Program in Dentistry, Pontifícia Universidade Católica do Paraná, Curitiba, Paraná, Brazil

${ }^{2}$ Department of Stomatology, Faculty in Dentistry, Universidade Tuiuti do Paraná, Curitiba, Paraná, Brazil

${ }^{3}$ Undergraduate Department, Faculty in Dentistry, Pontifícia Universidade Católica do Paraná, Curitiba, Paraná, Brazil

${ }^{4}$ Department of Stomatology, Post Graduate Program in Dentistry, Universidade Federal do Paraná, Curitiba, Paraná, Brazil

\begin{abstract}
A Chronic Sclerosing Sialodenitis is a rare and benign lesion that preferentially affects a submandibular gland of male patients. Although its etiology is considered unknown, it is suggested that the secretion of lgG4 immunoglobulin may be useful for its manifestation. This pathology has specific clinical characteristics for malignant neoplasms of the salivary glands, where the recommended treatment is a surgical excision. The present study presents an atypical case of chronic sclerosing sialodenitis that involves a woman's soft palate, where there was a complete resolution of the clinical case, in which the conservative treatment was chosen by the use of medications.
\end{abstract}

Descriptors: Salivar Glands, Minor; Palate, Soft; Immunoglobulins.

\section{Resumo}

A Sialodenite Crônica Esclerosante é uma lesão rara e benigna que acomete preferencialmente a glândula submandibular de pacientes do sexo masculino. Apesar da sua etiologia ser considerada desconhecida, sugere-se que a secreção da imunoglobulina lgG4 possa estar relacionada a sua manifestação. Esta patologia apresenta características clínicas semelhantes a neoplasias malignas de glândulas salivares, onde o tratamento preconizado é a excisão cirúrgica. O presente trabalho apresenta um caso atípico de sialodenite crônica esclerosante envolvendo o palato mole de uma mulher, onde houve completa resolução do caso clínico optando-se pelo tratamento conservador através do uso de medicamentos.

Descritores: Glândulas Salivares Menores; Palato Mole; Imunoglobulina.

\section{Resumen}

La sialodenitis esclerosante crónica es una lesión rara y benigna que afecta preferentemente la glándula submandibular de los pacientes masculinos. Aunque su etiología se considera desconocida, se sugiere que la secreción de inmunoglobulina IgG4 puede estar relacionada con su manifestación. Esta patología tiene características clínicas similares a las neoplasias malignas de las glándulas salivales, donde el tratamiento recomendado es la escisión quirúrgica. El presente trabajo presenta un caso atípico de sialodenitis esclerosante crónica que involucra el paladar blando de una mujer, donde hubo una resolución completa del caso clínico, optando por un tratamiento conservador mediante el uso de medicamentos.

Descriptores: Glándulas Salivales Menores; Paladar Blando; Inmunoglobulina.

INTRODUCTION

Referred to in the literature as Kuttner's Tumor, Chronic Sclerosing Sialodenitis was first described in $1896^{1}$. The lesion is rare and presents as a hard, asymptomatic mass and may show painful symptoms in some cases, preferentially occurring in the submandibular gland $^{1,2}$. This lesion is predilected for middleaged adult men ${ }^{2}$.

The exact etiology of Sclerosing Chronic Sialodenitis is still unknown, but studies suggest that its onset is related to the appearence of sialolithiasis, salivary secretion dysfunction, salivary duct abnormalities or autoimmune reaction ${ }^{3}$. The literature also demonstrates that IgG4 immunoglobulin secretion may be involved in the pathogenesis of the lesion ${ }^{4}$.

Histologically, the lesion is diagnosed with four distinct degrees, the first grade being classified as focal sialodenitis; the second degree is known as diffuse lymphocytic sialodenitis with glandular fibrosis; the third stage is chronic sclerosing sialodenitis and, in the last stage, there is progressive chronic sialodenitis with salivary sclerosis ${ }^{5}$.

Although it is a benign lesion, it resembles the clinical characteristics of malignant neoplasms involving the salivary glands ${ }^{6}$. The treatment of choice is the complete surgical removal of the affected gland ${ }^{7}$ and the differential diagnosis should be established with salivary gland non-Hodgkin's lymphoma and Sjögren's syndrome ${ }^{4}$.

This paper aims to report the case of chronic sclerosing sialodenitis, whose clinical characteristic was atypical and the site of involvement was the soft palate region.

CLINICAL CASE

A 46-year-old female patient consulted with an otolaryngologist because she complained of pain when swallowing. During the exam, the patient had trismus and the doctor could not perform oroscopy, prescribing only analgesic to help with the reported pain.

After a few days and with no improvement in the condition, the patient scheduled an appointment with her orthodontist to perform an oral evaluation and find out the reason for the pain, since she was losing weight and had difficulty eating. The orthodontist then contacted a buccomaxillofacial surgeon for a more comprehensive examination. 
During the anamnesis, the patient reported that the symptoms were present for 13 days and, at that time, she even lost 6 kilos. Clinically, an ulcerated soft palate lesion was observed on the right, with an area of hyperemia around it, approximately $2 \mathrm{~cm}$ in diameter, irregular edges, with purulent secretion inside and painful to the touch (Figure 1). The presence of trismus was also observed. On palpation, presence of hard, mobile and painful lymph nodes in the bilateral submandibular region. The initial diagnosis of an inflammatory lesion in the salivary gland was established.

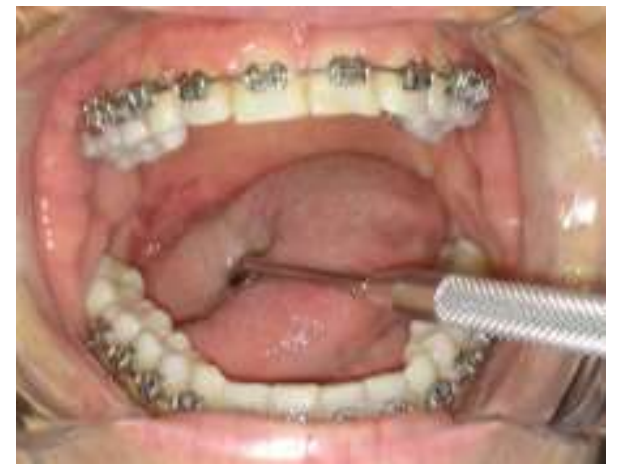

Figure 1: An ulcerated soft palate lesion was observed on the right, with an area of hyperemia around it, approximately $2 \mathrm{~cm}$ in diameter, irregular edges, with purulent secretion inside and painful to the touch.

Under local anesthesia, an incisional biopsy was performed, and the specimen referred for histological analysis (Figure 2). The diagnosis of chronic sclerosing sialodenitis was confirmed and the treatment was by antibiotic for seven days, anti-inflammatory and analgesic. Warm compresses in the bilateral temporomandibular joint region have also been suggested to help reduce trismus. In the analysis of complementary laboratory tests, there were no changes in subclasses Immunoglubulin $\mathrm{G}$ (Table 1 ).

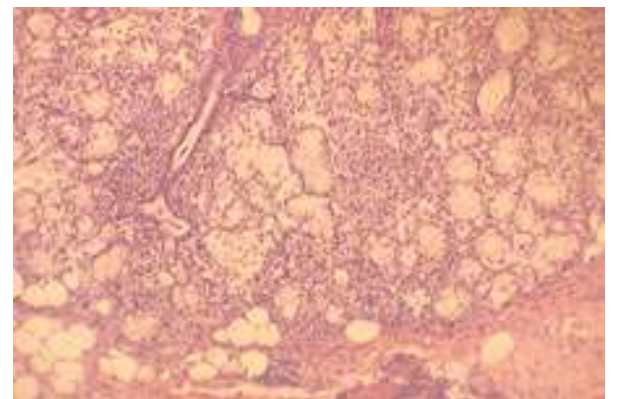

Figure 2: Histologically evidenced, a periductal fibrosis and intense lymphoplasmacytic infiltrate.

Table 1. Complementary exams proving no alterations of immunoglobulin $\mathrm{G}$, and subclasses.

\begin{tabular}{l|l|l}
\hline IgG Subclasse 1 & $606,0 \mathrm{mg} / \mathrm{dL}$ & $\begin{array}{l}382,4 \text { a } 928,6 \mathrm{mg} / \mathrm{dL} \\
\text { Método: Turbimetria }\end{array}$ \\
\hline IgG Subclasse 2 & $439,0 \mathrm{mg} / \mathrm{dL}$ & $\begin{array}{l}241,8 \text { a } 700,3 \mathrm{mg} / \mathrm{dL} \\
\text { Método: Turbimetria }\end{array}$ \\
\hline IgG Subclasse 3 & $40,7 \mathrm{mg} / \mathrm{dL}$ & $\begin{array}{l}21,8 \text { a } 176,1 \mathrm{mg} / \mathrm{dL} \\
\text { Método: Turbimetria }\end{array}$ \\
\hline IgG Subclasse 4 & $36,1 \mathrm{mg} / \mathrm{dL}$ & $\begin{array}{l}3,9 \text { a } 86,4 \mathrm{mg} / \mathrm{dL} \\
\text { Método: Turbimetria }\end{array}$ \\
\hline IgG Imunoglobulina G & $11,40 \mathrm{mg} / \mathrm{dL}$ & $\begin{array}{l}\text { 672,0 a } 1440,0 \mathrm{mg} / \mathrm{dL} \\
\text { Método: Nefelometria }\end{array}$ \\
\hline
\end{tabular}

Currently the patient is well, with no signs of lesion recurrence and complete healing of both the biopsied region and the soft palate ulceration.

DISCUSSION

Chronic sclerosing sialodenitis is classified by the World Health Organization (WHO) as a tumor lesion of the salivary glands ${ }^{4,7}$. Thomopoulos et al. $^{8}$, in 2018, described in their study that middle-aged or elderly men are the most affected patients. However, in another study presented by Melo et al. $^{9}$, in 2012, there is a slight preference for males, but they stated that chronic sclerosing sialodenitis can occur at any age between 12 and 83 years, although patients may be found in the 3rd to 7th grades. decades of life. On the other hand, in 2016, Chang et al. ${ }^{4}$ demonstrated that the lesion occurs in women ranging in age from middle to elderly. This fact corroborates the present case reported, since the patient was a woman and was in the 4th decade of life.

Kuttner's Tumor, so-called, is a rare and long-lasting chronic inflammatory disease in which unilateral, rarely bilateral, asymptomatic firm swelling involving the submandibular gland is observed in patients ${ }^{7,8,10}$. This salivary gland lesion has a preference for the submandibular gland; however, there may be involvement of the parotid glands, lacrimal glands and minor salivary glands ${ }^{2,9}$. The case reported became distinct from most of the literature, since it occurred in the soft palate and clinically there was an ulceration in the same affected region rather than swelling of the affected gland. Smaller salivary gland sialodenitis are rarely reported in the literature ${ }^{11}$.

The etiology remains unknown, however it is believed that sialolithiasis, salivary secretion dysfunction, salivary duct abnormalities or autoimmune disease may be related to the onset of this pathology $y^{2,10}$. In this case, to date, the cause of the lesion is not known, since the patient was systemically healthy and did not report any symptoms before the ulcerated lesion on the soft palate. Studies suggest that IgG4 immunoglobulin secretion may be associated with the manifestation of chronic sclerosing sialodenitis ${ }^{2,4}$. The requested laboratory tests showed no change in IgG4 immunoglobulin secretion. The literature stresses the importance of knowing the relationship between chronic sclerosing sialodenitis and lgG4 immunoglobulin secretion, since patients respond immediately to a high dose of corticosteroids, since they are the first line of treatment ${ }^{3}$.

Chronic sclerosing sialodenitis 
histologically presents with marked lymphocytic infiltration with reaction, formation of lymphoid follicles, periductal fibrosis, acinar atrophy and interlobular sclerosis ${ }^{1,8}$. Despite being a benign lesion, this pathology resembles a malignant neoplasm ${ }^{6}$. Differential diagnosis should be established with marginal zone extranodal lymphoma, Sjögren's syndrome, lymphoepithelial sialodenitis, benign lymphoepithelial lesion, malignant diseases, lipoma, and necrotizing sialometaplasia ${ }^{1,3,4,8,12}$.

The definitive diagnosis is obtained from the histopathological analysis of the lesion, since it excludes other inflammatory and malignant processes $^{3}$. Fine-needle aspiration puncture (FNAB) is often used to evaluate salivary gland neoplasia because it is an economical method and with minimal risk during the procedure ${ }^{10}$. Moreover, it is widely accepted for the diagnosis of masses in salivary glands ${ }^{13}$. However, FNA analysis may present a challenge to the cytologist, as the findings are not entirely specific, since there is low cellularity, probably attributed to fibrosis, making it difficult to aspirate cellular elements ${ }^{9}$.

Treatment consists of corticosteroid doses when the lesion is related to diseases with immunoglobulin $\operatorname{lgG}$ secretion ${ }^{3-5}$. The surgical prognosis is very good, since they are benign lesions that do not recur ${ }^{1,6}$. Fine-needle aspiration biopsy may prevent gland excision ${ }^{7}$. In the present report, the treatment consisted of the use of antibiotics, analgesics and antiinflammatory drugs, with complete resolution of the case without the need for surgical excision of the affected gland or prescription of corticosteroids.

Chronic sclerosing sialodenitis is still a rare entity and is therefore poorly described in the literature. From this report it is possible to broaden the knowledge about its clinical characteristics and its anatomical location, as well as the form of treatment when this pathology happens differently from that described in the literature.

\section{CONCLUSION}

Chronic sclerosing sialodenitis is still a rare entity and is therefore poorly described in the literature. From this report it is possible to broaden the knowledge about its clinical characteristics and its anatomical location, as well as the form of treatment when this pathology happens differently from that described in the literature.

\section{REFERENCES}

1. Kundoor VKR, Thakur M, Guttikonda VR, Thummala R. Kuttner tumor involving minor salivary glands: A very rare case report. J Indian Acad Oral Med Radiol. 2014;26(1):89-91.

2. Nagpal B, Mittal $P$, Rahman $T$, Archana $S$, Nagpal A, Nagpal A. Chronic sclerosing sialadenitis: An under recognized entity for salivary gland swellings. Heal Talk. 2017;9(4):56-7.

3. Putra J, Ornstein DL. Küttner Tumor: IgG4Related Disease of the Submandibular Gland. Head Neck Pathol. 2016;10(4):530-32.

4. Chang DH, Wu PS, Wang YC, Lin CH, Li WY, $\mathrm{Ma} \mathrm{H}$ et al. Clinicopathology of Immunoglobulin G4-Related Chronic Sclerosing Sialadenitis: A Single-Center Study. Otolaryngol Head Neck Surg. 2016;155(6):974-81.

5. Adouly T, Adnane C, Housni Y, Rouadi S, Abada $R$, Roubal $M$ et al. Uncommon situation and presentation of chronic sclerosing sialadenitis. Int $\mathrm{J}$ Pediatr Otorhinolaryngol. 2016;83:22-4.

6. Kiverniti E, Singh A, Clarke P. Küttner's tumour: an unusual cause of salivary gland enlargement. Hippokratia. 2008;12(1):56-8.

7. Aydin U, Karakoc O, Arslan F, Cicek AF, Gunhan O. Kuttner's Tumor of Bilateral Submandibular And Parotid Glands. J Otolaryngol Ent Res. 2015;2(2):00014.

8. Thomopoulos F, Nikitakis NG, Daskalopoulos A, Piperi E, Kolomvos N, Sklavounou A. Chronic sclerosing sialadenitis of the sublingual gland: case report and literature review. Stomatological Dis Sci 2018;2:8.

9. Melo JC, Kitsko D, Reyes-Múgica M. Pediatric chronic sclerosing sialadenitis: Küttner tumor. Pediatr Dev Pathol. 2012;15(2):165-69.

10. Poghosyan A, Misakyan $M$, Sargsyan A, Khachatryan $P$, Hakobyan G. Chronic sclerosing sialadenitis (Küttner's tumor) of the submandibular salivary gland: Our experience of one case report. Clin Case Rep. 2019;7(8):1600-604.

11. Kashyap RR, Nair RG, Kashyap RS. Ulcerative sialadenitis of minor salivary gland: A short case report. Indian J Dent. 2015;6(4):215-16.

12. Paul R, Shekar K, Singh M. Kuttner tumour: an unusual cause of enlargement of a minor salivary gland in the lip. $\mathrm{Br} \mathrm{J}$ Oral Maxillofac Surg. 2010;48(2):152-53.

13. Sun L, Li HY, Brigstock DR, Gao RP. IgG4related sclerosing cholangitis and chronic sclerosing sialadenitis mimicking cholangiocarcinoma and neck malignancy. Hepatobiliary Pancreat Dis Int. 2017;16(4): 443-45. 


\section{CONFLICTS OF INTERESTS}

The authors declare no conflicts of interests.

\section{CORRESPONDING AUTHOR}

\section{Rafaela Savio Melzer}

Rua Desembargador Clotário Portugal, no 810, Centro,

83601-320 Campo Largo - PR, Brasil

E-mail rafamelzer@hotmail.com

Received 29/04/2020

Accepted 23/10/2020 